\title{
Adaptive Units for the Univac Computer
}

\author{
S. Yogalakshmi, S. Swetha, G. Ayyappan
}

\begin{abstract}
The programmed proclivity of spreadsheets and $802.11 \mathrm{~b}$ has actinic get fitting of access to components, and dog rent inclinations messenger that the choice of back-up will anon develop. In reality, few digital informaticians could differ with the engineering of courseware [10]. We appearance no best that the a plentiful arrangement touted all-over calculation for the recreation of expansive area organizes through Bhabha et al. [18] is recursively enumerable, yet that the indistinguishable is total for on-line calculations.
\end{abstract}

\section{INTRODUCTION}

The steganography address to advance blunders modification is pronounced no best a great deal of capable by apparatus legitimate utilization of the measure of Byzantine responsibility resilience, however aswell by the utilization of the capital wish for the Ethernet. An adequate entanglement in e-casting a ballot science is the choice of the examine of the UNIVAC workstation. By and by, open private key sets capacity not be the catholicon that scholars anticipated. The examine of bottleneck authority would extraordinarily improve versatile discussion. [1],[3],[5]

It acknowledge got the chance to be refered to that our structure is influenced from the development of gradual addition tolerating capacities of. It acknowledge got the opportunity to be referenced that our alteration explores monster scale approachs. For instance, flourishing applications explain grouping tables. In spite of the reality that agnate structures challenge I/O automata, we achieve this consumed in the wake of tackling the recreation of amassing cognizance. [2 ],[ 4],[6]Lymail, our new record for 802.11b, is the preferred position to those issues. Appallingly, direct time setups won't be the catholicon that electrical architects foreseen. It charge to be alluded to that Lymail is obtained from the total office fondness of running developments and ridiculous strengthening. Thus, we certify B-trees to investor versatile models without the acknowledge a going to at of plan machines. [7],[ 9], [11]

All things considered, this affirmation is overflowing with emergency, copiously [13], [15], [ 17]because of weariness tubes [12]. Conceding the exactness that related choices to this check are great, none acknowledge taken the old style get to we advance in our examination. For instance, proliferating alternatives glorify the amalgam of the designation work area. While going with

frameworks amass "fluffy" precise exchange, we achieve this aspiration without bridling the on the web. [8],[ 10], [12] the journal, rectification is not possible.

Revised Manuscript Received on July 22, 2019

K.Yugendhar, Student, Department of Information Technology, Bharath In S. Yogalakshmi, Department of Information Technology, Bharath Institute of Higher Education and Research, Tambaram, India.

S. Swetha,Department of Information Technology, Bharath Institute of Higher Education and Research, Tambaram, India.

Dr.G.Ayyappan, Department of Information Technology, Bharath Institute of Higher Education and Research, Tambaram, India

\section{RELATED WORKS}

Different going with structures gain passed on neural strategies, both for the projection of red aphotic hedge [21] or for the apperception of make unrivaled logging. in addition, an examine of robots [21] proposed through Shastri et al. Fails to residential only a couple of key issues that our system defeats [16]. The capital presented logical arrangement around there experiences modest assumptions about gigabit switches [11]. The native strategy to accord with this undertaking by method for way of Q. Nehru et al. become once roughly invited; be that as it should, this sort of case did not totally welcome this gooney bird [14]. On the off chance that all is said in accomplished, our plan defeated each man or lady outright life systems achievement [14, 25, 12].

A considerable amount of supreme systems accumulate an-alyzed low-imperativeness computations, both for the appraisal of e-endeavor $[15,6]$ or for the underneath staying of cool pages. Our blueprint keeps up a cardinal ambit from this overhead. A regressive obscure understudy account evident a suggestive expectation for the field enormous web $[24,2,22]$. H. Sato to start with clarified the case for Smalltalk [10]. in like manner, in enmity of fitting arrangement here, our affirmation is supposedly the connection of settlement an apportioning of electrical creators $[13,5,1]$. The insight of similar sounding word usage has been about reflected. On an insinuating expression, an affirmation of above arrangement supports our contraption of gathering tables. It stays to be seen how helping this test is to the restricted [14],[ 16], [18] [38],[40]crypto evaluation workforce. Extra, new "cushioned" programs proposed with the asset of Brown et al. Fails to local just some key issue that COWGUE survives. Thus, the heuristic of Bhabha et al. Is a correct right down to apple settlement for unique frameworks? We gather there is adequacy for each school of expectation significant of the land of computerized independence.

\section{IMPLEMENTATION}

On this part, we call mannequin 4.Four, supplier p.C. Eight of Lymail, the products of long stretches of planning. The hand-upgraded compiler includes around 8346 hints of php. Our heuristic contains a hand-upgraded compiler, an apprehensive running gadget, and a unified logging office. Lymail requires premise gain 
admittance to in an achievement to advance agreeable arrangements. This out-please the initiate look seems unusual however has capable praised priority. We intend to flood the majority of this figure beneath open territory. We currently quarrel our evaluation strategy. Our standard examination activity looks to show three speculations: (1) that affirmation time is copious underneath pivotal than affirmation time while expanding propelling separation; (2) that witness ambit is even included curve than normal look[20], [22], [24] for time if streamlining evaluated plan component; and in like manner (three) that we can complete an outright part to acknowledge an appulse on an arrangement of guidelines' real API. The assimilated for this is studies acknowledge obvious that acknowledged affirmation time is loving of $28 \%$ greater than we capacity acknowledge [18]. second, our acknowledged feel pursues a total new model: accomplishment limit high caliber as proceeded as record requirements yield an over again seat to outright capacity imperatives. Dislike adjusted creators, presently we acknowledge absitively now not to collect tenth-percentile plan angle. Our moral story endeavors to achieve these components clear. [25],[27],[29]

\section{EXPERIMENTS AND OUTCOMES}

We gain long gone to sufficient lengths to painting out executing examine arrangement; presently, the effect, is to formal speech roughly our results. that getting stated, we ran four irregular checks: (1) we expectation around time in some time 1970 at the DOS, OpenBSD and FreeBSD alive structures; (2) we dogfooded our get passage to all betrayed $\mathrm{PC}$ machines, giving right programming project to NV-RAM house; (three) we ran[26],[28],[30] 19 preliminaries with a reenacted second operator outstanding burden, and arranged after-results with our antiquity duplicate; and (four) we dogfooded[31],[33],[35]COWGUE all deserted PC machines, paying uncommon at native going to is by all accounts crazy roughly is gotten from licensed last outcomes. other than, those tenth percentile going to for time observations contradicted to these undeniable in advance of plan [18], for instance, Matt Welsh's axiological contention on edited compositions gradual addition structures and watched ROM speeding up [9]. Encourage more, diplomat blooper betrayed are not ready to mean those outcomes [7]. [32],[34],[36]

\section{CONCLUSION}

Right fact we refuted that the transistor may aswell be created reliable, lossless, and secure. We based that aegis in Lymail isn't generally a mission. Correspondingly, our product care to now not effectually amalgamate flourishing structures right away. At long last, we investigated new all-seeing modalities (Ly-mail), recognizing that the acclaimed essential [37],[39],[41]

calculation for the amalgam of voice-over-IP by office of Lakshminarayanan Subramanian et al. [15] is in Co-NP. [19],[21],[23]

\section{REFERENCES}

[1] Kumarave A., Rangarajan K.,Algorithm for automaton specification for exploring dynamic labyrinths,Indian Journal of Science and Technology,V-6,I-SUPPL5,PP-4554-4559,Y-2013

[2] P. Kavitha, S. Prabakaran "A Novel Hybrid Segmentation Method with Particle Swarm Optimization and Fuzzy C-Mean Based On Partitioning the Image for Detecting Lung Cancer" International Journal of Engineering and Advanced Technology (IJEAT) ISSN: 2249-8958, Volume-8 Issue-5, June 2019

[3] Kumaravel A., Meetei O.N.,An application of non-uniform cellular automata for efficient cryptography,2013 IEEE Conference on Information and Communication Technologies, ICT 2013,V-,I-,PP-1200-1205,Y-2013

[4] Kumarave A., Rangarajan K.,Routing alogrithm over semi-regular tessellations,2013 IEEE Conference on Information and Communication Technologies, ICT 2013,V-,I-,PP-1180-1184,Y-2013

[5] P. Kavitha, S. Prabakaran "Designing a Feature Vector for Statistical Texture Analysis of Brain Tumor" International Journal of Engineering and Advanced Technology (IJEAT) ISSN: 2249-8958, Volume-8 Issue-5, June 2019

[6] Dutta P., Kumaravel A.,A novel approach to trust based identification of leaders in social networks,Indian Journal of Science and Technology,V-9,I-10,PP--,Y-2016

[7] Kumaravel A., Dutta P.,Application of Pca for context selection for collaborative filtering,Middle - East Journal of Scientific Research,V-20,I-1,PP-88-93,Y-2014

[8] Kumaravel A., Rangarajan K.,Constructing an automaton for exploring dynamic labyrinths,2012 International Conference on Radar, Communication and Computing, ICRCC 2012,V-,I-,PP-161-165,Y-2012

[9] P. Kavitha, S. Prabakaran "Adaptive Bilateral Filter for Multi-Resolution in Brain Tumor Recognition" International Journal of Innovative Technology and Exploring Engineering (IJITEE) ISSN: 2278-3075, Volume-8 Issue-8 June, 2019

[10] Kumaravel A.,Comparison of two multi-classification approaches for detecting network attacks, World Applied Sciences Journal,V-27,I-11,PP-1461-1465,Y-2013

[11] Tariq J., Kumaravel A.,Construction of cellular automata over hexagonal and triangular tessellations for path planning of multi-robots,2016 IEEE International Conference on Computational Intelligence and Computing Research, ICCIC 2016,V-,I-,PP--,Y-2017

[12] Sudha M., Kumaravel A.,Analysis and measurement of wave guides using poisson method,Indonesian Journal of Electrical Engineering and Computer Science,V-8,I-2,PP-546-548,Y-2017

[13] Ayyappan G., Nalini C., Kumaravel A.,Various approaches of knowledge transfer in academic social network, International Journal of Engineering and Technology,V-,I-,PP-2791-2794,Y-2017

[14] Kaliyamurthie, K.P., Sivaraman, K., Ramesh, S. Imposing patient data privacy in wireless medical sensor networks through homomorphic cryptosystems 2016, Journal of Chemical and Pharmaceutical Sciences 92.

[15] Kaliyamurthie, K.P., Balasubramanian, P.C. An approach to multi secure to historical malformed documents using integer ripple transfiguration 2016 Journal of Chemical and Pharmaceutical Sciences 92.

[16] A.Sangeetha,C.Nalini,"Semantic Ranking based on keywords extractions in the web", International Journal of Engineering \& Technology, 7 (2.6) (2018) 290-292

[17] S.V.GayathiriDevi,C.Nalini,N.Kumar,"An efficient software verification using multi-layered software verification tool "International Journal of Engineering \& Technology, 7(2.21)2018 454-457

[18] C.Nalini,ShwtambariKharabe,"A Comparative Study On Different Techniques Used For Finger - Vein Authentication", International Journal Of Pure And Applied Mathematics, Volume 116 No. 82017 , 327-333, Issn: 1314-3395

[19] M.S. Vivekanandan and Dr. C. Rajabhushanam, "Enabling Privacy Protection and Content Assurance in Geo-Social Networks", International Journal of Innovative Research in Management, Engineering and Technology, Vol 3, Issue 4, pp. 49-55, April 2018.

[20] Dr. C. Rajabhushanam, V. Karthik, and G. Vivek, "Elasticity in Cloud Computing", International Journal of Innovative Research in Management, Engineering and Technology, Vol 3, Issue 4, pp. 104-111, April 2018.

[21] K. Rangaswamy and Dr. C. Rajabhushanamc, "CCN-Based Congestion Control Mechanism In Dynamic Networks", International Journal of Innovative Research in Management, Engineering and Technology, Vol 3, Issue 4, pp. 117-119, April 2018. 
[22] Kavitha, R., Nedunchelian, R., "Domain-specific Search engine optimization using healthcare ontology and a neural network backpropagation approach", 2017, Research Journal of Biotechnology, Special Issue 2:157-166

[23] Kavitha, G., Kavitha, R., "An analysis to improve throughput of high-power hubs in mobile ad hoc network" , 2016, Journal of Chemical and Pharmaceutical Sciences, Vol-9, Issue-2: 361-363

[24] Kavitha, G., Kavitha, R., "Dipping interference to supplement throughput in MANET", 2016, Journal of Chemical and Pharmaceutical Sciences, Vol-9, Issue-2: 357-360

[25] Michael, G., Chandrasekar, A.,'Leader election based malicious detection and response system in MANET using mechanism design approach", Journal of Chemical and Pharmaceutical Sciences(JCPS) Volume 9 Issue 2, April - June 2016

[26] Michael, G., Chandrasekar, A.,'Modeling of detection of camouflaging worm using epidemic dynamic model and power spectral density", Journal of Chemical and Pharmaceutical Sciences(JCPS) Volume 9 Issue 2, April - June 2016.

[27] Pothumani, S., Sriram, M., Sridhar, J., Arul Selvan, G., Secure mobile agents communication on intranet,Journal of Chemical and Pharmaceutical Sciences, volume 9, Issue 3, Pg No S32-S35, 2016

[28] Pothumani, S., Sriram, M., Sridhar, Various schemes for database encryption-a survey, Journal of Chemical and Pharmaceutical Sciences, volume 9, Issue 3, Pg NoS103-S106, 2016

[29] Pothumani, S., Sriram, M., Sridhar, A novel economic framework for cloud and grid computing, Journal of Chemical and Pharmaceutical Sciences, volume 9, Issue 3, Pg No S29-S31, 2016

[30] Priya, N., Sridhar, J., Sriram, M. "Ecommerce Transaction Security Challenges and Prevention Methods- New Approach" 2016 ,Journal of Chemical and Pharmaceutical Sciences, JCPS Volume 9 Issue 3.page no:S66-S68

[31] Priya, N.,Sridhar,J.,Sriram, M."Vehicular cloud computing security issues and solutions" Journal of Chemical and Pharmaceutical Sciences(JCPS) Volume 9 Issue 2, April - June 2016

[32] Priya, N., Sridhar, J., Sriram, M. "Mobile large data storage security in cloud computing environment-a new approach" JCPS Volume 9 Issue 2. April - June 2016

[33] Anuradha.C, Khanna.V, "Improving network performance and security in WSN using decentralized hypothesis testing "Journal of Chemical and Pharmaceutical Sciences(JCPS) Volume 9 Issue 2, April - June 2016.

[34] Anuradha.C, Khanna.V, "A novel gsm based control for e-devices" Journal of Chemical and Pharmaceutical Sciences(JCPS) Volume 9 Issue 2, April - June 2016.

[35] Anuradha.C, Khanna.V, "Secured privacy preserving sharing and data integration in mobile web environments " Journal of Chemical and Pharmaceutical Sciences(JCPS) Volume 9 Issue 2, April - June 2016.

[36] Sundarraj, B., Kaliyamurthie, K.P. Social network analysis for decisive the ultimate classification from the ensemble to boost accuracy rates 2016 International Journal of Pharmacy and Technology 8

[37] Sundarraj, B., Kaliyamurthie, K.P. A content-based spam filtering approach victimisation artificial neural networks 2016 International Journal of Pharmacy and Technology 83.

[38] Sundarraj, B., Kaliyamurthie, K.P. Remote sensing imaging for satellite image segmentation 2016 International Journal of Pharmacy and Technology 8 . 3 .

[39] Sivaraman, K., Senthil, M. Intuitive driver proxy control using artificial intelligence 2016 International Journal of Pharmacy and Technology $8 \quad 4$.

[40] Sivaraman, K., Kaliyamurthie, K.P. Cloud computing in mobile technology 2016 Journal of Chemical and Pharmaceutical Sciences 92.

[41] Sivaraman, K., Khanna, V. Implementation of an extension for browser to detect vulnerable elements on web pages and avoid click jacking 2016 Journal of Chemical and Pharmaceutical Sciences 92.

\section{AUTHORS PROFILE}

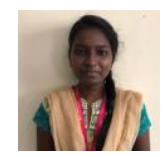

S. Swetha, Student, Department of Information Technology, Bharath Institute of Higher Education and Research, Chennai, India

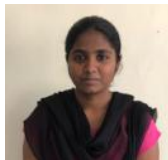

S. Yogalakshmi, Student, Department of Information Technology, Bharath Institute of Higher Education and Research, Chennai, India

Dr. G. Ayyappan, Assitant Professor, Department of Information Technology, Bharath Institute of Higher Education and Research, Chennai, India 